\title{
Mass spectrometry of refractory black carbon particles from six sources: carbon-cluster and oxygenated ions
}

\author{
J. C. Corbin ${ }^{1}$, B. Sierau ${ }^{1}$, M. Gysel ${ }^{2}$, M. Laborde' ${ }^{2, *}$, A. Keller ${ }^{3}$, J. Kim ${ }^{4}$, A. Petzold ${ }^{4, * *}$, T. B. Onasch ${ }^{5,6}$, U. Lohmann ${ }^{1}$, \\ and A. A. Mensah ${ }^{1}$ \\ ${ }^{1}$ ETH Zurich, Institute for Atmospheric and Climate Science, Zurich, Switzerland \\ ${ }^{2}$ Paul Scherrer Institute, Laboratory of Atmospheric Chemistry, 5232 Villigen PSI, Switzerland \\ ${ }^{3}$ Institute of Aerosol and Sensor Technology, University of Applied Sciences Northwestern Switzerland, Windisch, \\ Switzerland \\ ${ }^{4}$ Deutsches Zentrum für Luft- und Raumfahrt, Institut für Physik der Atmosphäre, 82234 Oberpfaffenhofen, Germany \\ ${ }^{5}$ Aerodyne Research Inc., Billerica, Massachusetts, USA \\ ${ }^{6}$ Boston College, Chestnut Hill, Massachusetts, USA \\ * now at: Aerosol Consulting ML GmbH, Ennetbaden, Switzerland, \& Ecotech Pty Ltd., Australia \\ ** now at: Institut für Energie- und Klimaforschung IEK-8: Troposphäre, Forschungszentrum Jülich GmbH, 52425 Jülich, \\ Germany
}

Correspondence to: J. C. Corbin (joel.corbin@env.ethz.ch)

Received: 20 September 2013 - Published in Atmos. Chem. Phys. Discuss.: 24 October 2013

Revised: 31 January 2014 - Accepted: 5 February 2014 - Published: 13 March 2014

\begin{abstract}
We discuss the major mass spectral features of different types of refractory carbonaceous particles, ionized after laser vaporization with an Aerodyne high-resolution soot-particle aerosol mass spectrometer (SP-AMS). The SPAMS was operated with a switchable $1064 \mathrm{~nm}$ laser and a $600^{\circ} \mathrm{C}$ thermal vaporizer, yielding respective measurements of the refractory and non-refractory particle components. Six samples were investigated, all of which were composed primarily of refractory material: fuel-rich and fuel-lean propane/air diffusion-flame combustion particles; graphitespark-generated particles; a commercial fullerene-enriched soot; Regal Black, a commercial carbon black; and nascent aircraft-turbine combustion particles.

All samples exhibited a spectrum of carbon-cluster ions $\mathrm{C}_{x}^{n+}$ in their refractory mass spectrum. Smaller clusters $(x<$ 6) were found to dominate the $\mathrm{C}_{x}^{n+}$ distribution. For fullerene soot, fuel-rich-flame particles and spark-generated particles, significant $\mathrm{C}_{x}^{n+}$ clusters at $x \gg 6$ were present, with significant contributions from multiply charged ions $(n>1)$. In all six cases, the ions $\mathrm{C}_{1}^{+}$and $\mathrm{C}_{3}^{+}$contributed over $60 \%$ to the total $\mathrm{C}_{1<x<16}^{+}$intensity. Furthermore, the ratio of these major ions $\mathrm{C}_{1}^{+} / \mathrm{C}_{3}^{+}$could be used to predict whether significant $\mathrm{C}_{x}^{n+}$ signals with $x>5$ were present. When such signals were present, $\mathrm{C}_{1}^{+} / \mathrm{C}_{3}^{+}$was close to 1 . When absent, $\mathrm{C}_{1}^{+} / \mathrm{C}_{3}^{+}$
\end{abstract}

was $<0.8$. This ratio may therefore serve as a proxy to distinguish between the two types of spectra in atmospheric SPAMS measurements.

Significant refractory oxygenated ions such as $\mathrm{CO}^{+}$and $\mathrm{CO}_{2}^{+}$were also observed for all samples. We discuss these signals in detail for Regal Black, and describe their formation via decomposition of oxygenated moieties incorporated into the refractory carbon structure. These species may be of importance in atmospheric processes such as water uptake and heterogeneous chemistry.

If atmospherically stable, these oxidized species may be useful for distinguishing between different combustion sources. If unstable, they may provide a means to estimate the atmospheric age of an rBC sample. Future studies should attempt to establish which of these scenarios is more realistic.

\section{Introduction}

Combustion-generated particles represent the most efficient light-absorbing particles in the atmosphere. In addition to affecting the radiative balance of the earth, such particles may also enhance glacial melting (Flanner et al., 2007), alter 
convection and precipitation (Ramanathan and Carmichael, 2008), react with atmospheric trace gases (Monge et al., 2010), and serve as cloud condensation (Hitzenberger et al., 2003; Tritscher et al., 2011; Engelhart et al., 2012; Martin et al., 2012) and possibly ice nuclei (DeMott et al., 1999; Koehler et al., 2009; Corbin et al., 2012). Consideration of the short atmospheric lifetime (days to weeks, Cape et al., 2012), human health effects, and damage to crops associated with combustion-generated particles has led to their being highlighted as ideal candidates for near-term climate mitigation (Shindell et al., 2012; Bond et al., 2013).

While the light-absorbing component of combustion particles is a major anthropogenic climate-warming agent, its warming effect can be counteracted by light-scattering from internally mixed, non-absorbing material (IPCC, 2007; Ramanathan and Carmichael, 2008; Bond et al., 2013). Depending on the combustion, significant amounts of such material may be emitted at the source (Bond et al., 2013). Coemitted reactive gases may be oxidized in the atmosphere to form less volatile compounds, which condense onto absorbing particles and significantly increase their non-absorbing fraction over time (Cappa et al., 2013). This so-called secondary material is frequently hygroscopic, affecting particle cloud droplet activation and thus lifetime, in addition to radiative properties (Bond et al., 2013). Yet secondary material, in particular particulate secondary organic matter (SOM), is not well represented by most climate models (Bond et al., 2013). Thus, quantification of the composition and evolution of the light-absorbing and the non-absorbing components of combustion particles is a current topic of major interest (Cappa et al., 2012, 2013; Jacobson, 2013).

The need for an improved representation of the mixing of light-absorbing particles with secondary material motivates the atmospheric source apportionment of aged, combustiongenerated particles. Techniques to measure and apportion combustion emissions to their sources include radiocarbon measurements (e.g., Zencak et al., 2007); X-ray, Raman or electron spectroscopy (Robertson, 2002); the combination of elemental carbon measurements with other tracers (e.g., Jeong et al., 2013); measurements of light-absorption Ångström exponents (e.g., Sandradewi et al., 2008); and single-particle mass spectrometry (e.g., Toner et al., 2008). The first three of these methods require offline filter analysis and do not provide high-time-resolution information. High-time-resolution measurements of light-absorbing carbonaceous particles are made by a number of mass- or lightabsorption-based instruments (e.g., Petzold and Schönlinner, 2004; Laborde et al., 2012), but mass spectrometry stands out for its ability to characterize chemical differences between combustion particles. Such chemical characterization may provide information on particle source, mixing state (Liu et al., 2013), and chemical evolution.

Commercial aerosol mass spectrometers typically employ either thermal-desorption or laser desorption/ionization (LDI) vaporizers. Thermal-desorption vaporization does not detect the refractory, light-absorbing carbon of combustion particles. On the other hand, LDI mass spectrometers may detect both refractory and non-refractory components. These mass spectrometers are often capable of detecting individual particles, which might thereafter be attributed to specific sources, such as different vehicle types (Toner et al., 2008). Multiple studies have correlated single-particle LDI signals with collocated mass measurements in order to estimate chemically resolved mass loadings (Pratt and Prather, 2012; Healy et al., 2013). However, the sensitivity of LDI to matrix-influenced charge-transfer reactions (Reilly et al., 2000) and to the particle-to-particle variability of reactions within the ablation plume (Reinard and Johnston, 2008) hinders a robust quantification of atmospheric aerosols.

Although not able to directly measure refractory carbon species, the Aerodyne aerosol mass spectrometer (AMS) (Jayne et al., 2000; Canagaratna et al., 2007) has in recent years been pivotal in quantifying source contributions to organic aerosol loadings (Zhang et al., 2011). The AMS quantifies non-refractory particulate matter (NR-PM) by thermaldesorption vaporization at $600{ }^{\circ} \mathrm{C}$, followed by a separate electron-impact ionization step. This two-step vaporizationionization process yields especially reproducible mass spectra, facilitating mass quantification (Jimenez et al., 2003). Yet the AMS does not vaporize refractory particulate matter (RPM) such as that in dust, sea salt, or refractory black carbon particles (rBC).

A modified AMS, the soot-particle AMS (SP-AMS), addresses this limitation with the addition of a $1064 \mathrm{~nm}$ laser vaporizer (Onasch et al., 2012). Whereas the AMS vaporizes only NR-PM, the SP-AMS vaporizes $1064 \mathrm{~nm}$ lightabsorbing refractory particulate matter (LR-PM) via radiative heating. LR-PM includes $\mathrm{rBC}$ as a subset. During radiative heating of LR-PM, any less-refractory PM internally mixed with LR-PM may be vaporized by conduction. This commonly includes such species as sulfates, nitrates, and organic matter. These conductively vaporized species distinguish the SP-AMS from incandescence-based techniques such as the single-particle soot photometer (SP2), which quantify $\mathrm{rBC}$ mass based only on the refractory particulate component that is heated to $\mathrm{rBC}$ vaporization temperature. The relationship between these PM subsets is further illustrated in the Supplement (Sect. S1).

This paper presents a discussion of the SP-AMS mass spectra of six types of $\mathrm{rBC}$ particles. The six samples comprise five laboratory aerosols as well as emissions from an aircraft engine within a test cell at the Zurich Airport in Switzerland. The discussion emphasizes refractory mass spectral features relevant to the interpretation of ambient SPAMS measurements. First, signals from carbon-cluster ions were considered. Two ratios between the most common such ions were identified, and were directly related to the overall carbon-cluster ion distribution. For an atmospheric aerosol containing a variety of rBC types, this result may be useful in apportioning the SP-AMS carbon-cluster signals between 
sources. Second, oxygenated-carbon ions originating from the $\mathrm{rBC}$ were identified and attributed to refractory oxygenated moieties within the $\mathrm{rBC}$. The potential atmospheric impacts of these ions are discussed.

\section{Experimental}

\subsection{Laboratory setup}

A series of laboratory experiments were performed in January 2012 as part of an intensive laboratory campaign, "BCAct". This campaign was undertaken at ETH Zurich to investigate the physical, chemical and optical properties of various $\mathrm{rBC}$ particle types using a range of techniques.

The laboratory setup is shown in Fig. 1. rBC particles were generated by various methods (Sect. 2.3), diluted when necessary, and introduced into a chamber with a residence time of approximately $30 \mathrm{~min}$. Oil-free stainless-steel tubing was used prior to the SP-AMS. All gases used were of high purity (grade 5.6 synthetic air, grade 6.0 nitrogen, grade 6.0 argon). Dilution was achieved using either an ejector diluter (VKL10, PALAS GmbH, Germany) with synthetic air or a filter system. The filter system split samples between two short parallel sections of tubing, one of which contained both a filter and a valve; the valve was used to control the degree of sample filtration. From the residence chamber, particles were passed through two bipolar chargers, split into two equal sample flows, and size-selected by a differential mobility analyzer (DMA) in each line before characterization by a suite of instruments. This suite included a singleparticle soot photometer (SP2) and aerosol particle mass analyzer (APM), which measure incandescent $\mathrm{rBC}$ mass and shape-independent single-particle mass, respectively. These SP2 and APM data were used as a reference for the nonrefractory mass contained in the different $\mathrm{rBC}$ particle types (Sect. S7). A previous publication has discussed selected single-particle soot photometer (SP2) results from this study (Gysel et al., 2012); the present work focusses on results obtained with the SP-AMS.

The two DMAs (DMA 1: custom-built (Winklmayr et al., 1991; Wiedensohler et al., 2012); DMA 2: TSI model 3071, TSI Inc., Minnesota, USA) were each calibrated using polystyrene latex spheres of the diameters used in the experiments. The calibration particles were $125 \mathrm{~nm}$ (Duke Scientific Corp., Palo Alto, USA), $200 \mathrm{~nm}$ (Duke Corp.) and $305 \mathrm{~nm}$ (BS-Partikel GmbH, Wiesbaden, Germany) in diameter. Some experiments were also performed with $500 \mathrm{~nm}$ selected particles and polydisperse aerosols. The sample flow rate through each DMA was consistent at $2 \mathrm{Lmin}^{-1}$, with a $5 \mathrm{Lmin}^{-1}$ sheath flow. The DMA resolution - the ratio of the maximum to the full-width-half-maximum of the predicted DMA transfer function - was therefore 2.5. This is lower than the manufacturer-recommended resolution of 10 , and was chosen to maximize the particulate mass loading

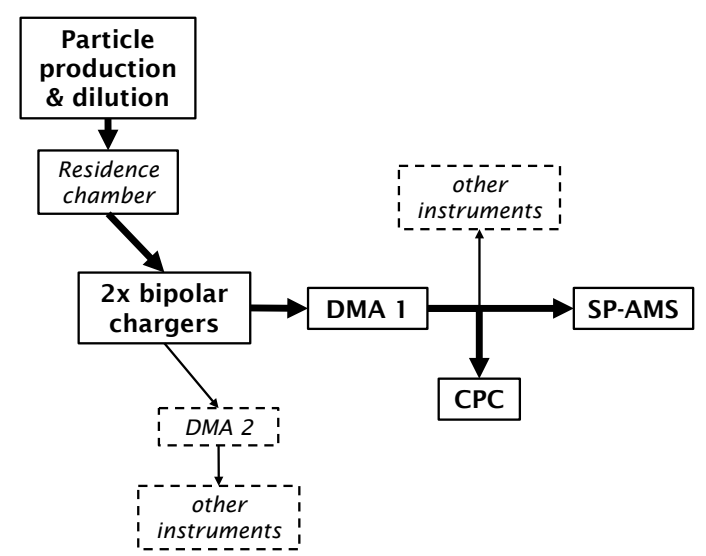

Fig. 1. Laboratory setup used for all samples except turbine particles. Aerosols were diluted before passing through a $1 \mathrm{~m}^{3}$ residence chamber with residence time $\sim 30 \mathrm{~min}$. Particles then flowed through two bipolar chargers at $4 \mathrm{~L} \mathrm{~min}^{-1}$ before being split equally between two DMAs.

downstream of the DMA. This setting gives a broad-enough transfer function that a minor overlap would have occurred between different size-selected experiments (Table 1). A condensation particle counter (CPC, model 3010, TSI Inc. USA) monitored particle number concentrations during each experiment.

\subsection{Soot-Particle Aerosol Mass Spectrometer}

The Aerodyne soot-particle aerosol mass spectrometer (SPAMS) is an evolution of the Aerodyne high-resolution time-of-flight aerosol mass spectrometer (AMS), to include a continuous-wave $1064 \mathrm{~nm}$ laser vaporizer. In this section we describe the operation principles of the standard AMS, followed by a description of the SP-AMS and its sampling configuration.

The AMS (Aerodyne Research Inc., Massachusetts, USA) has been described in detail by Jayne et al. (2000) and Canagaratna et al. (2007). Briefly, aerosols are sampled through an aerodynamic lens to focus particles before they enter a vacuum chamber. Upon entering the chamber, particles are accelerated to their size-dependent terminal velocity and traverse a sizing region before reaching the vaporizer. The AMS vaporizer is a porous-tungsten inverted cone held at $600^{\circ} \mathrm{C}$, which flash-vaporizes non-refractory aerosol components before $70 \mathrm{eV}$ electron-impact ionization (EI) and highresolution time-of-flight mass analysis. Interference by gases and internal background signals is accounted for by regularly blocking incoming particles with a mechanical disc, as well as periodically filtering the sampled aerosol. In an alternate mode of operation, the mechanical disc is continuously rotated, and positioned such that particles are pulsed through a mechanical slit on its edge. This so-called particle time-of-flight (PToF) mode allows measurements to be taken 
Table 1. Summary of samples, sizes measured, and experimental programme.

\begin{tabular}{llll}
\hline Aerosol & Abbreviation & Mobility Diameter [nm] & Date \\
\hline CAST Black & CBK & $125,200,305$ & Jan 26 \\
CAST Brown & CBW & $125,200,305$ & Jan 27 \\
Spark-generated particles & GFG & $125,200,305,500$ & Jan 30 \\
Regal Black & RB & $125,200,305,500$ & Jan 31 \\
Fullerene-Enriched Soot & FS & $125,200,305,500$ & Feb 1 \\
Thermodenuded CBW & CBWTD & $125,200,305$ & Feb 2 \\
Aircraft gas-turbine particles & TU & Polydisperse (mode 25) & Apr 30 \\
\hline
\end{tabular}

as a function of particle vacuum aerodynamic diameter at the cost of signal-to-noise; the chopper has a duty cycle of only $1 \%$. We refer to "MS mode" to distinguish normal measurements from PToF measurements.

The SP-AMS (Onasch et al., 2012) is identical to the AMS but for the addition of a switchable, active-cavity, continuous-wave $1064 \mathrm{~nm}$ Nd:YAG laser (Droplet Measurement Technologies, CO, USA). The laser is similar to that used by the SP2 (Schwarz et al., 2006; Laborde et al., 2012) but has higher fluence. The laser is installed orthogonally to both the particle beam and ion extraction path, intersecting the EI ionization chamber. Whereas the AMS detects only NR-PM, the SP-AMS vaporizes LR-PM by radiative heating (notably $\mathrm{rBC}$ and metals) as well as PM associated with LR-PM by conductive heating, as described in the introduction. After vaporization, EI ionization and mass analysis proceed in a similar fashion to the AMS. The different modes of vaporization in the AMS and SP-AMS may result in differences between the internal energies of the resulting vapors, which may influence consequent EI fragmentation patterns (Alfarra, 2004; Onasch et al., 2012).

In this study, the AMS and SP-AMS vaporizers were employed simultaneously, such that particles transited through the laser beam on their way to the AMS vaporizer. Laserabsorbing particles such as $\mathrm{rBC}$ particles are therefore expected to vaporize within the laser beam, without reaching the AMS vaporizer (Onasch et al., 2012). The SP-AMS laser was switched on and off during sampling, to obtain both "regular" AMS mass spectra (laser off) and SP-AMS mass spectra (laser on). The AMS vaporizer was always on. The ion time-of-flight chamber was operated in the shorter of two flight modes (V-mode), utilizing a single pass through the reflectron. PToF mode was employed $25 \%$ of the time for all laboratory samples and measurements were averaged over 90 s. Data were analyzed using the community AMS analysis software SQUIRREL (version 1.51H) and PIKA (version $1.10 \mathrm{H}$ ) as well as custom code written in Igor Pro (version 6, WaveMetrics Inc., USA).

\subsection{Particle sources}

Five types of $\mathrm{rBC}$ particles were produced in the laboratory by combustion, spark-generation or nebulization of commer- cial samples. A sixth sample was measured directly behind an aircraft turbine at a commercial turbine servicing facility (SR Technics, Zurich Airport, Switzerland). Table 1 gives a summary of the measurement schedule.

\subsubsection{CAST Black (CBK) and CAST Brown (CBW)}

A combustion aerosol standard burner (CAST, model 004, Jing Ltd., Zollikofen, Switzerland) produced particles via a propane diffusion flame. Manufacturer characterization has been published online at http://www.sootgenerator.com/publ. $\mathrm{htm}$. The CAST burner was used to produce two types of particles. The first type, referred to as CAST "Black" (CBK), was produced at a fuel-equivalence ratio $\phi=0.85$ (carbon-to-oxygen ratio $\mathrm{C} / \mathrm{O}=0.25$ ), and contained little organic matter. The second type, referred to as CAST "Brown" (CBW) after its visual appearance on a filter, was produced by a fuel-rich flame $(\phi=1.36 ; \mathrm{C} / \mathrm{O}=0.41)$ and contained significant amounts of OM (Fig. S2). Additional experiments were performed with $\mathrm{CBW}$ after thermodenuding at $250^{\circ} \mathrm{C}$. Denuding reduced the organic mass to near-detection-limit for the AMS.

\subsubsection{GFG spark-generated particles (GFG)}

A PALAS GFG 1000 spark generator (Helsper et al., 1993) produced carbonaceous particles by repeated electrical discharge across graphite electrodes. The PALAS GFG generator was sparked at $75 \mathrm{~Hz}$ in an argon atmosphere (grade 6.0), with no additional dilution. GFG particles are morphologically similar to diesel particles (Weingartner et al., 1995; Burtscher, 2005; Schneider et al., 2006), although their microstructure and chemistry are significantly different (Saathoff et al., 2003; Schmid et al., 2011).

\subsubsection{Regal Black (RB)}

Regal Black (Cabot REGAL R400 pigment black), a carbon black distributed by Cabot Corp., USA, is the recommended calibration standard for the SP-AMS (Onasch et al., 2012). A sample of Regal Black from lot no. GP-3901 was received from Aerodyne Research Inc. to ensure consistency. The RB sample was suspended in Milli-Q water and nebulized with 
grade 5.6 synthetic air in a homebuilt Collison-type nebulizer, before drying within a silica gel diffusion dryer.

\subsubsection{Fullerene-enriched particles (FS)}

Fullerene-enriched carbonaceous particles were obtained from Sigma-Aldrich ("fullerene soot as produced", lot no. MKBB8240V). These particles are produced by resistive heating of graphite such that carbonaceous nanoparticles nucleate above the graphite surface (Krätschmer et al., 1990). When performed under $\sim 10 \mathrm{kPa}$ helium, this process results in nanoparticles containing $\sim 7 \mathrm{wt} \%$ fullerenes $(\sim 6 \mathrm{wt} \%$ $\mathrm{C}_{60}, \sim 1 \mathrm{wt} \% \mathrm{C}_{70}$ ) (Sigma-Aldrich, personal communication, 2012). FS is commonly used to calibrate single-particle soot photometers (SP2) instruments, as its incandescence-to$\mathrm{rBC}$-mass response is similar to that of $\mathrm{rBC}$ in ambient and diesel exhaust particles (Moteki and Kondo, 2010; Laborde et al., 2012).

\subsubsection{Aircraft gas-turbine engine emissions (TU)}

In a separate experiment to the laboratory campaign, emissions from a civil aviation gas turbine were sampled directly behind the engine. The turbine, a CFM56-5B4-2P engine, is commonly used by modern, short-haul civilian aircraft. Turbine exhaust was sampled through an $8 \mathrm{~mm}$ inner diameter, stainless steel, single-point sampling probe. The probe occupied a single, fixed position directly within the engine exhaust stream. The measurements reported here were taken from an undiluted "ICAO Annex 16" industry-standard sampling line (Crayford, 2012) and represent fuel-rich combustion. Additional details on the sampling configuration and data analysis for TU are given in the Supplement (Sect. S7.3).

\section{Results and discussion}

The dual vaporizer configuration of the SP-AMS (Sect. 2.2) allowed the laser vaporizer to be switched periodically on or off while the thermal vaporizer remained continuously on. In laser-on mode, $\mathrm{rBC}$ particles are expected to vaporize within the laser, along with any internally mixed non-absorbing material volatile below $4000 \mathrm{~K}$. In laser-off mode, only NR-PM is observed, which in this study was largely organic matter $(\mathrm{OM})$. To distinguish between these two modes, we will refer to "SP-AMS" (laser on) and "AMS" (laser off) data, along with the terms $\mathrm{rBC}$ and $\mathrm{OM}$.

The results presented here will focus on those massspectral signals present only with the SP-AMS laser on, i.e., the refractory component of the particles. All SP-AMS mass spectra contained carbon-ion clusters $\mathrm{C}_{x}^{n+}$ as the major signals. In general, these signals were negligible in AMS mass spectra, as shown by Fig. 2. The figure compares the AMS and SP-AMS signals at $\mathrm{C}_{1}^{+}$and $\mathrm{C}_{3}^{+}$on the lower ordinate. Two sequential monodisperse experiments are shown, at 200 and $305 \mathrm{~nm}$. The upper ordinate shows that CPC num-

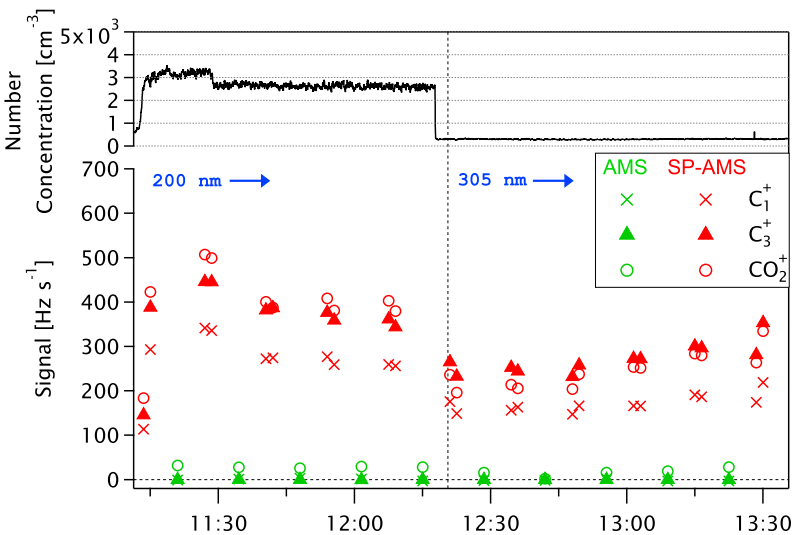

Fig. 2. Lower ordinate: time series of $\mathrm{C}_{1}^{+}(\times), \mathrm{C}_{3}^{+}(\triangle)$, and $\mathrm{CO}_{2}^{+}$ (o) for Regal Black during two size-selected experiments for AMS (green symbols) and SP-AMS (red symbols) measurements. Upper ordinate: CPC particle number concentration time series.

ber concentrations were stable throughout the period. While clear $\mathrm{C}_{1}^{+}$and $\mathrm{C}_{3}^{+}$signals were observed by the SP-AMS (red symbols), the AMS data (green) were at or below detection limit. These refractory $\mathrm{C}_{x}^{n+}$ signals are discussed in detail in Sect. 3.1.

In addition to $\mathrm{C}_{x}^{n+}$, significant SP-AMS signals were detected from refractory particulate $\mathrm{CO}^{+}$and $\mathrm{CO}_{2}^{+}$. Figure 2 additionally shows the time series of $\mathrm{CO}_{2}^{+}$in circle symbols on the lower ordinate. The signal clearly increases during SPAMS measurement (red). Relative to $\mathrm{C}_{x}^{+}$, a significant $\mathrm{CO}_{2}^{+}$ signal remains in AMS periods. This is discussed in Sect. 3.2.

\subsection{Carbon-cluster fragmentation patterns}

The following subsections present a general description of each of the $\mathrm{C}_{x}^{n+}$ fragmentation patterns (Sect. 3.1.1) followed by an intercomparison of the $\mathrm{C}_{x}^{+}$patterns for the six samples (Sect. 3.1.2).

\subsection{1 $C_{x}^{n+}$ ions}

For all six samples, carbon clusters containing 1 to 3 atoms $\left(\mathrm{C}_{1-3}^{+}\right)$dominated the SP-AMS mass spectrum, as illustrated by Fig. 3 . The figure shows the percentage contribution of $\mathrm{C}_{1-3}^{+}$to the total $\mathrm{C}_{x}^{n+}$ signal for $n=1$ and $1<x<16$ $\left(\mathrm{C}_{1-16}^{+}\right)$. In total, $\mathrm{C}_{1-3}^{+}$made up $60-85 \%$ of the $\mathrm{C}_{1-16}^{+}$signal depending on the sample. The two ions $\mathrm{C}_{1}^{+}$and $\mathrm{C}_{3}^{+}$each contributed at least $30 \%$ of $\mathrm{C}_{1-16}^{+}$for all samples. For $\mathrm{C}_{2}^{+}$, the contributions ranged from 3-18\%. This is consistent with the expected higher stability of odd-numbered, positively charged carbon clusters (Raghavachari and Binkley, 1987).

Carbon-cluster ions with $x>16$ and $n>1$ were observed for three samples: GFG, CBW, and, especially, FS. Since in general these signals were highest for FS, we believe that they originated from pre-existing fullerene molecules within the $\mathrm{rBC}$ particles. However, our data do not rule out the 


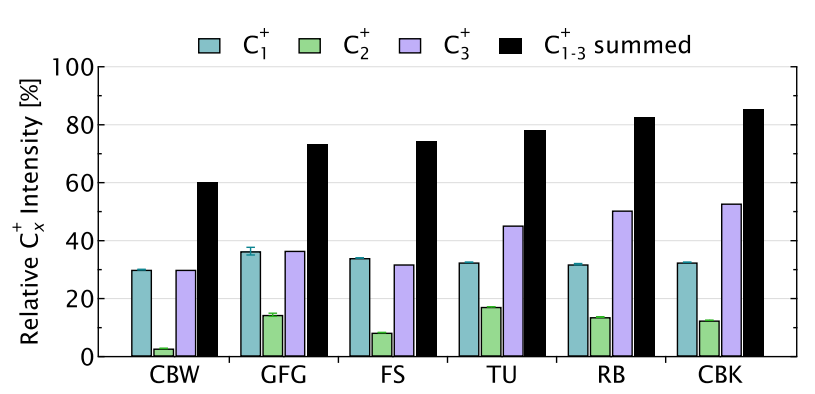

Fig. 3. Percentage contribution of $\mathrm{C}_{1-3}^{+}$ions to the sum of $\mathrm{C}_{x}^{+}$signals $(1<x<16)$ for CAST "Brown" (CBW), spark-generated particles (GFG), fullerene-enriched soot (FS), aircraft-turbine particles (TU), Regal Black (RB), and CAST "Black" (CBK), in order of increasing $\mathrm{C}_{1-3}^{+}$intensity. Error bars for $\mathrm{C}_{1}^{+}$to $\mathrm{C}_{3}^{+}$are propagated from Poisson ion counting statistics. The data represent an average over all selected sizes.

possibility that fullerenes, or simply larger carbon clusters, may form within the instrument during particle vaporization. Previous work by Onasch et al. (2012) also identified significant signals at $\mathrm{C}_{x>16}^{+}$originating from a sample of denuded flame soot. They attributed signals above $m / z 384$ to fullerenes, and smaller ions to linear or ring structures.

For all samples presented here, peaks at $\mathrm{C}_{x>16}^{+}$were generally less intense than peaks at $\mathrm{C}_{x<6}^{+}$. For example, for FS the most intense peak above the mass-to-charge ratio of $\mathrm{C}_{16}^{+}$ $(m / z 192)$ was at $m / z 216$, and was only $2.6 \%$ as intense as the peak at $m / z$ 36. Moreover, this $m / z 216$ peak included signals from not only $\mathrm{C}_{18}^{+}$, but also from $\mathrm{C}_{36}^{2+}$ and $\mathrm{C}_{54}^{3+}$. The presence of these multiply charged ions was evidenced by the isotope peaks ${ }^{13} \mathrm{C}_{1}{ }^{12} \mathrm{C}_{35}^{2+}(\mathrm{m} / \mathrm{z} 216.50),{ }^{13} \mathrm{C}_{1}{ }^{12} \mathrm{C}_{54}^{3+}$ (216.33) and ${ }^{13} \mathrm{C}_{2}{ }^{12} \mathrm{C}_{53}^{3+}$ (216.66). No other multiply charged peaks were present at $m / z 216.00$, as confirmed by the absence of significant ${ }^{13} \mathrm{C}_{1}{ }^{12} \mathrm{C}_{71}^{4+}$ signal at $m / z$ 216.25. The peak areas of ${ }^{13} \mathrm{C}_{1}^{12} \mathrm{C}_{35}^{2+}$ and ${ }^{13} \mathrm{C}_{1}{ }^{12} \mathrm{C}_{54}^{3+}$ could therefore be combined with the isotopic abundance of ${ }^{13} \mathrm{C}_{1}$ to estimate the contributions of $\mathrm{C}_{18}^{+}, \mathrm{C}_{36}^{2+}$, and $\mathrm{C}_{54}^{3+}$ to $\mathrm{m} / z 216.00$ (Fig. S3). We found that $\mathrm{C}_{36}^{2+}$ contributed the majority of the signal at $m / z 216.00$, representing $62.8 \pm 0.8 \%$ of the total. Of the remainder, the majority was due to $\mathrm{C}_{18}^{+}(33.1 \pm 0.6 \%)$. $\mathrm{C}_{54}^{3+}$ contributed only $4.1 \pm 0.6 \%$. Extrapolating this result to all $\mathrm{C}_{x>16}^{+}$peaks suggests that fullerene ions dominated the high $-m / z$ range, although ring structures were present in non-negligible amounts. This is in contrast to Onasch et al. (2012), who did not report multiply charged ions.

A high intensity of multiply charged $\mathrm{C}_{x}^{n+}$ ions is expected for fullerenes - which exist for $\mathrm{C}_{x>30}$ (von Helden et al., 1993) - due to their unique electronic and geometric structure (Scheier et al., 1994; Matt et al., 1996). However, ring- or linear-shaped carbon clusters at $\mathrm{C}_{x<36}$ may also acquire multiple charges. In the FS mass spectrum discussed above, we observed multiply charged $\mathrm{C}_{3}$ via the iso- tope ion ${ }^{13} \mathrm{C}_{1}{ }^{12} \mathrm{C}_{2}^{2+}$ at $m / z$ 18.050. This ion indicated that $\mathrm{C}_{3}^{2+}$ was present at only $5 \%$ of the $\mathrm{C}_{3}^{+}$intensity. This is consistent with the much higher energy required to form smaller, doubly charged $\mathrm{C}_{x}^{n+}$ ions (Díaz-Tendero et al., 2002; Zimmerman et al., 1991). The relative intensity of multiply charged ions is therefore low for smaller $\mathrm{C}_{x}^{+}$ions, but high for fullerenes. Because of the potential for misinterpreting these multiply charged fullerene ions, and potential differences in their production between instruments, their abundance should be checked in future SP-AMS studies.

In order to present carbon-cluster mass spectra for higher $x$, we restricted the present analysis to nominally singly charged $\mathrm{C}_{x}^{+}$ions with $1<x<16(\mathrm{~m} / z, 12-200)$ and their corresponding ${ }^{13} \mathrm{C}_{1} \mathrm{C}_{x-1}^{+}$daughters. This may include interferences from multiply charged $\mathrm{C}_{x}^{n+}$ with $m / z=12 n$, along with ${ }^{13} \mathrm{C}_{2}{ }^{12} \mathrm{C}_{x-2}^{2 n+}$ isotope ions. The $\mathrm{C}_{x}^{+}$mass spectra for all samples are given in Figs. S4-S9. Constraining the present discussion to $\mathrm{C}_{1-16}^{+}$allows a representation of the highestintensity ions while avoiding ambiguity for CBW, where significant PAH signals at high $\mathrm{m} / z(>200)$ were difficult to distinguish from $\mathrm{C}_{x}^{n+}$ signals in our mass spectra. We will below refer to the set of considered ions as $\mathrm{C}_{x}^{+}$.

\subsection{2 $\mathrm{C}_{1}^{+} / \mathrm{C}_{3}^{+}$to distinguish $\mathrm{rBC}$ types}

Given that $\mathrm{C}_{1}^{+}$and $\mathrm{C}_{3}^{+}$represented the majority of the $\mathrm{C}_{x}^{+}$ signal from all six samples, and that $\mathrm{C}_{x}^{+}$represented the majority of SP-AMS signals, this section explores the possibility of using these two ions as markers to distinguish between different sources of $\mathrm{rBC}$ based on their carbon-cluster fragments.

The ratio of signal intensities at $\mathrm{C}_{1}^{+}$and $\mathrm{C}_{3}^{+}$are plotted in Fig. 4 for all samples and mobility diameters listed in Table 1 . The figure shows the 25 th to 75 th percentile as a box, with whiskers extending to the 10th and 90th percentile. The horizontal line across each box represents the median. The data include a large range of signal intensities: ion rates for GFG were a factor of 20 lower than for CBW, while CBK ion rates were a factor of 3 higher. The samples fall broadly into two categories, with FS, GFG, CBW and CBWTD all having $\mathrm{C}_{1}^{+} / \mathrm{C}_{3}^{+}$close to 1 , while $\mathrm{TU}, \mathrm{RB}$ and $\mathrm{CBK}$ each have $\mathrm{C}_{1}^{+} / \mathrm{C}_{3}^{+}<0.8$. The range of values for $\mathrm{TU}$ is especially narrow due to the fact that one stable engine condition is presented, as described in Sect. S7.3 of the Supplement. In order to verify that the $\mathrm{C}_{1}^{+} / \mathrm{C}_{3}^{+}$ratio is reproducible, we compared our $\mathrm{RB} \mathrm{C}_{1}^{+} / \mathrm{C}_{3}^{+}$ratio to that measured using a different instrument at Aerodyne Research Inc. but the same RB sample (Onasch et al., 2012). Onasch et al. observed a $\mathrm{C}_{1}^{+} / \mathrm{C}_{3}^{+}$ratio of 0.63 (o in Fig. 4). The present data have a mean $\mathrm{C}_{1}^{+} / \mathrm{C}_{3}^{+}$ ratio of 0.67 ( $\times$ in Fig. 4), indicating that the $\mathrm{C}_{1}^{+} / \mathrm{C}_{3}^{+}$ratio may be a reproducible characteristic of this sample. 


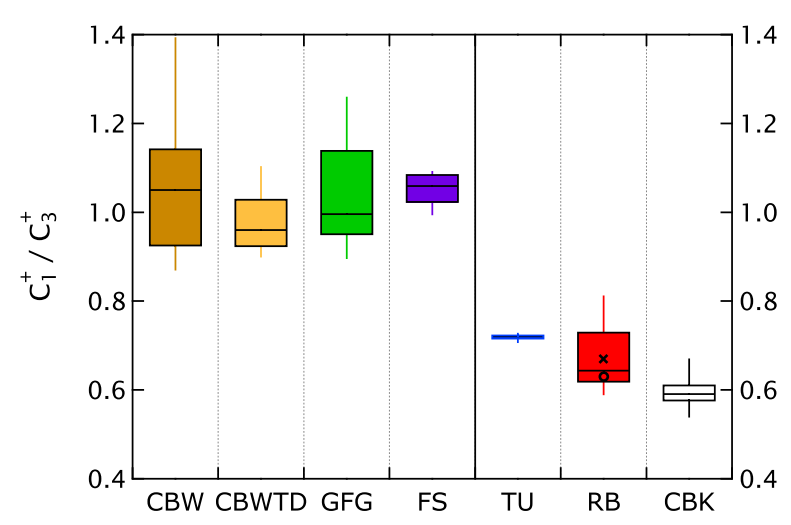

Fig. 4. SP-AMS $\mathrm{C}_{1}^{+} / \mathrm{C}_{3}^{+}$ratios for CAST "Brown" particles (CBW), thermodenuded CBW (CBWTD), spark-generated particles (GFG), fullerene-enriched soot (FS), aircraft-turbine particles (TU), Regal Black (RB), and CAST "Black" particles (CBK). All samples were monodisperse particles at multiple sizes, except TU. Each box spans the 25th to 75th percentile. Vertical lines extend to the 10th and 90th percentiles. The horizontal line within each box shows the median. The mean $\mathrm{C}_{1}^{+} / \mathrm{C}_{3}^{+}$ratio for $\mathrm{RB}$ is shown for the present study $(\times)$ and for independent measurements by Onasch et al. (o).

We next hypothesized that the $\mathrm{C}_{1}^{+} / \mathrm{C}_{3}^{+}$ratio may depend on the chemical structure of the $\mathrm{rBC}$, and compared the $\mathrm{C}_{x}^{+}$ mass spectra of each sample relative to FS. FS was chosen as a reference since it is commercially available, commercially traceable, and gave high-intensity signals at a large $m / z$ range. Figure 5 shows the $\mathrm{C}_{x}^{+}$spectral intensity for each sample plotted against FS on a log-log scale. Each spectrum is normalized to unity and excludes isotope ions for clarity. Since all spectra were dominated by $\mathrm{C}_{1-3}^{+}$(Sect. 3.1.1), these ions are found near the top-right corner, as labeled in white for RB. The white labels also apply to all data points vertically above or below the $\mathrm{RB}$ data points. Ions $\mathrm{C}_{4-5}^{+}$lie near to each other. None of the signals for $\mathrm{C}_{>6}^{+}$were greater than $0.1 \%\left(10^{-3}\right)$ of the $\mathrm{C}_{x}^{+}$signal for $\mathrm{RB}, \mathrm{TU}$, or $\mathrm{CBK}$.

Figure 5 shows that the six mass spectra are grouped into the same two categories as the $\mathrm{C}_{1}^{+} / \mathrm{C}_{3}^{+}$ratios in Fig. 4 . The mass spectra of GFG and CBW fall near the $1: 1$ line and are therefore similar to FS. In contrast, TU, RB, and CBK are generally shifted downwards, due to the lower relative intensities of heavier ions. The $\mathrm{C}_{x}^{+}$spectra of FS, GFG, and $\mathrm{CBW}$ all contain significant signals up to and beyond $\mathrm{C}_{16}^{+}$, while TU, RB, and $\mathrm{CBK}$ were dominated by the smaller $\mathrm{C}_{1-5}^{+}$ clusters. For TU, RB and CBK, the contribution of $\mathrm{C}_{x}^{+}$ions with $x \geq 6$ was always less than $0.1 \%$ of the total $\mathrm{C}_{x}^{+}$. This absence was not due to a lack of sufficient signal: the CBK mass spectrum was obtained at signal intensities a factor of 60 higher than for GFG.

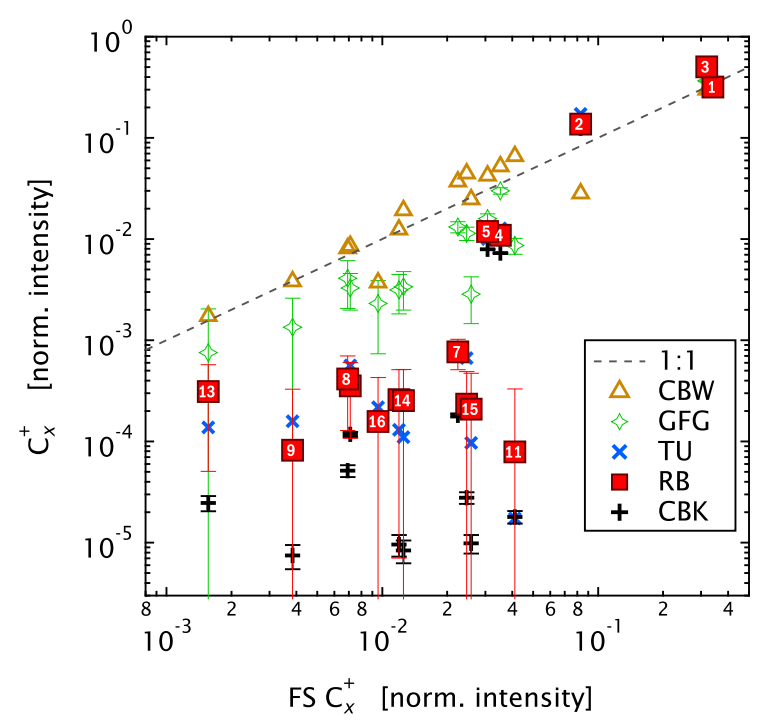

Fig. 5. Scatterplot of mass spectral intensities at each $\mathrm{C}_{x}^{+}$up to $x=16$. All spectra are normalized to unity and plotted against the $\mathrm{FS} \mathrm{C}_{x}^{+}$spectrum. The white numbers labeling RB (red squares) indicate the number of carbon atoms $x$ in each $\mathrm{C}_{x}^{+}$for both $\mathrm{RB}$ and FS. For clarity, some labels have been omitted, namely $\mathrm{C}_{x}^{+}$with $x=6$ (next to 8 ), 12 (next to 14), and 10 (next to 15). Error bars indicate ion counting uncertainties, and are not shown when they are smaller than the data symbols.

\subsubsection{Atmospheric suitability of $\mathrm{C}_{1}^{+} / \mathrm{C}_{3}^{+}$}

Minor quantities of $\mathrm{C}_{1}^{+}$and $\mathrm{C}_{3}^{+}$can be produced by organic molecules in the AMS and SP-AMS. These signals are typically negligible when compared to the overall AMS mass spectrum (e.g., Alfarra, 2004), but may be sufficient to interfere with $\mathrm{C}_{x}^{+}$signals from $\mathrm{rBC}$ during atmospheric sampling when organic mass fractions are high.

Since an organic molecule is more likely to form $\mathrm{C}_{1}^{+}$ions than $\mathrm{C}_{3}^{+}$ions, OM interference would be expected to artificially enhance the $\mathrm{C}_{1}^{+} / \mathrm{C}_{3}^{+}$ratio, thus potentially limiting the usefulness of the $\mathrm{C}_{1}^{+} / \mathrm{C}_{3}^{+}$ratio to distinguish between $\mathrm{rBC}$ sources. A simplistic solution to this problem for the dualvaporizer setup used here would be subtraction of the AMS $\mathrm{C}_{x}^{+}$signal from the SP-AMS $\mathrm{C}_{x}^{+}$signal. However, this may not be appropriate; Onasch et al. (2012) have observed a different fragmentation pattern when dioctyl sebacate was vaporized by AMS, compared to vaporization by SP-AMS after coating on glassy-carbon $\mathrm{rBC}$ spheres.

We tested the possibility of organic interference in our analysis by removing OM from CBW with a thermodenuder at $250^{\circ} \mathrm{C}$ prior to size selection. After thermodenuding, the AMS organic signal for $305 \mathrm{~nm}$ CBW particles was reduced to near-detection limit (Fig. S2), whereas the $\mathrm{C}_{1}^{+} / \mathrm{C}_{3}^{+}$ratio did not change appreciably (Fig. 4).

CBW had the highest OM content (based on the relative signal of AMS organics to $\mathrm{C}_{x}^{+}$ions) of the laboratory samples 
discussed herein. Nevertheless, $\mathrm{C}_{1}^{+}$signals were a factor of 250 lower in the AMS than in the SP-AMS for $305 \mathrm{~nm}$ non-thermodenuded CBW particles, and fell below detection limit for thermodenuded $305 \mathrm{~nm}$ CBW particles. A factor of 250 is large but not insignificant: the corresponding spherical-equivalent diameters required for a $1: 1$ AMS:SPAMS signal ratio at $\mathrm{C}_{1}^{+}$are approximately $50 \mathrm{~nm}$ for a $\mathrm{CBW}$ "core" and $440 \mathrm{~nm}$ for CBW organic matter, assuming respective material densities of $1.8 \mathrm{~g} \mathrm{~cm}^{-3}$ (Park et al., 2004) and $1.3 \mathrm{~g} \mathrm{~cm}^{-3}$ (Slowik et al., 2007). The CBW OM was dominated by PAHs (Fig. S2), which may have a $\mathrm{C}_{1}^{+}$yield different to that of typical ambient OM. However, this estimation indicates that $\mathrm{OM}$ mixed with $\mathrm{rBC}$ in ambient studies may significantly interfere with the determination of $\mathrm{C}_{1}^{+} / \mathrm{C}_{3}^{+}$ from ambient $\mathrm{rBC}$.

To avoid such interference, either organic material may be thermodenuded prior to sampling, or a different marker using higher-mass $\mathrm{C}_{x}^{+}$may be useful. All samples in the present study yielded carbon clusters $\mathrm{C}_{1-5}^{+}$. Considering all possible combinations of $\mathrm{C}_{1-5}^{+}$, we found that $\mathrm{C}_{4}^{+} / \mathrm{C}_{3}^{+}$is probably the best alternative ratio when organic interferences are significant (Fig. S10). Like $\mathrm{C}_{1}^{+} / \mathrm{C}_{3}^{+}$, this ratio also distinguishes between particle sources according to their $\mathrm{C}_{x}^{+}$mass spectra. The disadvantage of this ratio is its relatively lower limit of quantification: since fewer $\mathrm{C}_{4}^{+}$ions than $\mathrm{C}_{1}^{+}$ions are produced per unit mass of $\mathrm{rBC}$ vaporized, a higher $\mathrm{rBC}$ mass would be required to determine $\mathrm{C}_{4}^{+} / \mathrm{C}_{3}^{+}$rather than $\mathrm{C}_{1}^{+} / \mathrm{C}_{3}^{+}$. Additional studies using a variety of organic coatings should be performed to investigate whether such coatings influence these ratios.

\subsection{Refractory $\mathrm{CO}_{x}^{+}$signals $\left(\mathrm{rCO}_{x}\right)$}

\subsubsection{Identification of $\mathrm{rCO}_{x}$}

In addition to $\mathrm{C}_{x}^{n+}$, SP-AMS signals included oxygencontaining ions such as $\mathrm{CO}_{2}^{+}, \mathrm{CO}^{+}, \mathrm{H}_{2} \mathrm{O}^{+}, \mathrm{OH}^{+}$, and $\mathrm{O}^{+}$, which we refer to as $\mathrm{rCO}_{x}$. Because similar ions may also form from OM (both refractory and non-refractory), the identification and understanding of these signals is important for the interpretation of SP-AMS measurements from unknown samples. In this section, we discuss $\mathrm{rCO}_{x}$ signals from $\mathrm{RB}$. The focus is on $\mathrm{CO}_{2}^{+}$and $\mathrm{CO}^{+}$, since these ions could not have resulted from the ionization of residual water on the particles. We focus on RB as a model sample because its $\mathrm{C}_{x}^{n+}$ mass spectrum was dominated by the singly charged ions $\mathrm{C}_{1-5}^{+}$, simplifying its interpretation (Sect. 3.1.1). Additionally, RB is the recommended calibration standard for the SP-AMS (Onasch et al., 2012).

The refractory nature of $\mathrm{rCO}_{x}$ is illustrated by Fig. 6 . The figure plots the $\mathrm{PToF}$ spectrum at $\mathrm{m} / \mathrm{z} 28\left(\mathrm{~N}_{2}^{+}\right.$or $\mathrm{CO}^{+}$) for both AMS (green) and SP-AMS (red) operating modes while sampling polydisperse RB particles. The SP-AMS PToF spectrum of $m / z 36\left(\mathrm{C}_{3}^{+}\right.$, black symbols $)$ is shown for reference. Symbols represent raw data, while

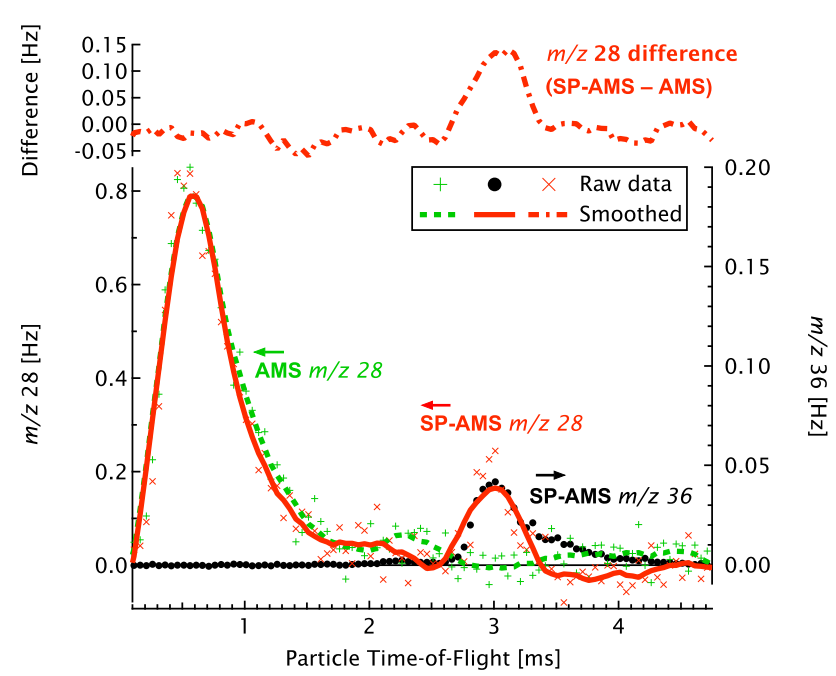

Fig. 6. Signal at $m / z, 28\left(\mathrm{~N}_{2}^{+}\right.$or $\left.\mathrm{CO}^{+}\right)$and $m / z, 36\left(\mathrm{C}_{3}^{+}\right)$as a function of particle time-of-flight for polydisperse RB particles. Data symbols show the raw SP-AMS or AMS data, which have been smoothed by a Savitsky-Golay filter for clarity when the signalto-noise was low (curves). The first peak $(0.6 \mathrm{~ms})$ corresponds to gas-phase $\mathrm{N}_{2}$, the second $\left(3 \mathrm{~ms}\right.$ ) to $\mathrm{CO}^{+}$originating from the $\mathrm{RB}$ particles. The upper panel (dash-dotted line) shows the difference of the SP-AMS and AMS curves.

curves represent smoothed data (using a 4th-order, 25-point Savitsky-Golay filter to preserve peak shape). Both the red SP-AMS and green AMS $m / z 28$ curves show a strong peak from gas-phase $\mathrm{N}_{2}$, at approximately $0.6 \mathrm{~ms}$. However, only the SP-AMS shows a second peak at $3 \mathrm{~ms}$. This peak is clearly within the particle phase, and corresponds to a mode vacuum-aerodynamic diameter of $386 \pm 1 \mathrm{~nm}$. This second peak is coincident with the arrival of the RB particles, as demonstrated by the coincident peak at $m / z 36$. We infer that the second $\mathrm{m} / z 28$ peak at $3 \mathrm{~ms}$ most likely originated from $\mathrm{CO}^{+}$formed when the $\mathrm{rBC}$ was vaporized.

The peak at $m / z 36$ is broad and possibly bimodal, whereas the peak at $m / z 28$ appears to decrease faster than at $m / z$ 36. This suggests that the refractory $\mathrm{CO}^{+}$content of $\mathrm{RB}$ is a function of particle size. A size dependence is also indicated by a decreasing ratio of $\mathrm{CO}_{2}^{+}$to $\mathrm{C}_{3}^{+}$with increasing mobility diameter for size-selected experiments. In these experiments, the $\mathrm{CO}_{2}^{+} / \mathrm{C}_{3}^{+}$ratio decreased from $1.6(125 \mathrm{~nm})$ to $0.8(500 \mathrm{~nm})$. The PToF signal at $m / z 44\left(\mathrm{CO}_{2}^{+}\right)$also peaked simultaneously with $m / z 36\left(\mathrm{C}_{3}^{+}\right)$(Fig. S11), demonstrating its particulate origin as previously observed by Onasch et al. (2012).

The relative significance of $\mathrm{rCO}_{x}$ was estimated by comparing the areas of log-normal curves fitted to the polydisperse $\mathrm{PToF}$ spectra. Bimodal fits were used for particulate $m / z 36\left(\mathrm{C}_{3}^{+}\right)$and $m / z 44\left(\mathrm{CO}_{2}^{+}\right)$. The estimated $\mathrm{CO}_{2}^{+} / \mathrm{C}_{3}^{+}$ ratio was 1.0 , consistent with the ratio found from the sizeselected measurements. The corresponding $\mathrm{CO}^{+} / \mathrm{C}_{3}^{+}$ratio was estimated as 20 , but may be positively biased by 
interference from $\mathrm{N}_{2}^{+}$. Furthermore, this ratio cannot be interpreted as a direct mass ratio before accounting for the ionization efficiencies of both $\mathrm{C}_{x}^{+}$and $\mathrm{rCO}_{x}^{+}$. When accounting for $\mathrm{C}_{x}^{+}$and not $\mathrm{rCO}_{x}$, the ionization efficiency of $\mathrm{RB}$ is 0.1 (Onasch et al., 2012), suggesting that a mass-weighted $\mathrm{CO}^{+} / \mathrm{C}_{3}^{+}$ratio may be lower. For a mass-weighted ratio, the ionization efficiencies of both $\mathrm{C}_{x}^{+}$and $\mathrm{rCO}_{x}$ must be known. Nevertheless, such a high ratio indicates clearly that $\mathrm{rCO}_{x}$ species are an important component of RB.

Significantly higher PToF signals in the SP-AMS than the AMS were also observed at other $m / z$ such as $18\left(\mathrm{H}_{2} \mathrm{O}^{+}\right), 17$ $\left(\mathrm{OH}^{+}\right)$and $16\left(\mathrm{O}^{+}\right)$for RB. Furthermore, significant $\mathrm{rCO}_{x}$ signals were also observed for every sample discussed above. The potential origin and significance of these signals are discussed in the next section.

\subsubsection{Origin of $\mathrm{rCO}_{x}^{+}$}

The observation of increased $\mathrm{rCO}_{x}^{+}$within the SP-AMS relative to the AMS mass spectrum could be due to (1) oxygenated functional groups incorporated into the refractory structure of the $\mathrm{rBC}$, (2) fragmentation of refractory OM, (3) $\mathrm{CO}$ or $\mathrm{CO}_{2}$ adsorbed to the particle surface, (4) gaseous $\mathrm{CO}$ or $\mathrm{CO}_{2}$ trapped within internal voids, or (5) reaction of carbon vapor with gas-phase $\mathrm{O}_{2}$. This section will argue that the first possibility is the most likely, and discuss the implications.

The second possibility is unlikely, since the SP-AMS mass spectrum of RB did not contain significant signals from hydrocarbon ions $\left(\mathrm{C}_{x} \mathrm{H}_{y}^{+}, \mathrm{C}_{x} \mathrm{H}_{y} \mathrm{O}^{+}\right.$, etc.) even though the signal intensity of $\mathrm{rCO}_{2}^{+}$was close to that of $\mathrm{C}_{3}^{+}$in the $\mathrm{RB}$ mass spectrum. Thus, any refractory organic molecules would have to include a negligible contribution of carbonhydrogen bonds, while simultaneously being large enough to be non-volatile at $600^{\circ} \mathrm{C}$. Moreover, for RB, these molecules would have had to form during its industrial production from hydrocarbon oils at $1500^{\circ} \mathrm{C}$. This combination of properties is physically unreasonable.

The third and fourth possibilities are not likely to be the major source of $\mathrm{rCO}_{x}$ in RB. Desorption of adsorbed $\mathrm{CO}_{2}$ is expected to occur within minutes (Sevilla and Fuertes, 2011). The $30 \mathrm{~min}$ residence chamber used in the current experiments should have provided sufficient time for desorption after nebulizing in $\mathrm{CO}_{2}$-free gas (Sect. 2.1). Voids within $\mathrm{RB}$ particles containing $\mathrm{CO}_{2}(\mathrm{~g})$, would contain very little $\mathrm{CO}_{2}$ mass per particle, since the density of $\mathrm{CO}_{2}(\mathrm{~g})$ is a factor of 1000 smaller than that of $\mathrm{rBC}$, yet the observed $\mathrm{CO}_{2}^{+} / \mathrm{C}_{3}^{+}$ ratio was $0.8-1.6$. Finally, the fifth possibility would yield $\mathrm{C}_{x} \mathrm{O}^{+}$and not $\mathrm{CO}_{2}^{+}$as the major product (von Helden et al., 1993). Such ions were not observed. Therefore, only the first possibility can be the major source of the observed $\mathrm{rCO}_{x}$.

Oxygenated moieties incorporated into the refractory carbon structure of RB are expected based on its production method. $\mathrm{RB}$ is produced by atomizing a proprietary oil within a furnace at $1800 \mathrm{~K}$, resulting in a "carbon black" that con- tains only $0.5-1 \mathrm{wt} \%$ of material volatile at $1223 \mathrm{~K}$. This carbon black is then treated with an unspecified, $\mathrm{HNO}_{3}$-like acid (Cabot Corp., personal communication, 2013), likely at elevated temperatures (Otake and Jenkins, 1993), in order to increase surface functionalization. This increased functionalization is indicated by an increase in the percentage of mass volatile at $1223 \mathrm{~K}$, from $0.5-1 \mathrm{wt} \%$ to $3.5 \mathrm{wt} \%$.

The acid treatment of $\mathrm{rBC}$ yields oxygenated moieties including hydroxyl, carbonyl, carboxyl, lactone, and acid anhydride groups, depending on the reaction time (Sellitti et al., 1990; Vinke et al., 1994; Figueiredo et al., 1999, 2007). These groups thermally decompose into $\mathrm{CO}$ or $\mathrm{CO}_{2}$ when heated slowly $\left(\sim 5 \mathrm{~K} \mathrm{~min}^{-1}\right)$ under inert atmospheres, typically at 500-1200 K depending on the functional group and heating rate (Zielke et al., 1996; Figueiredo et al., 1999, 2007). The thermal decomposition of such rBC surface groups should therefore be expected in the SP-AMS. The decomposition temperature of oxygenated moieties also relates to possibility (3) above: if such moieties decompose at $500-1200 \mathrm{~K}$, then no distinction between refractory, adsorbed $\mathrm{CO}_{2}(\mathrm{~g})$ and chemically bonded moieties can be made.

\subsubsection{Atmospheric relevance of $\mathrm{rCO}_{x}^{+}$}

In an atmospheric context, oxygenated surface groups may feasibly form via reaction with oxidants such as $\mathrm{O}_{2}$ (Otake and Jenkins, 1993; Figueiredo et al., 1999), ozone (e.g., McCabe and Abbatt, 2008) as well as other atmospheric oxidants (Saathoff et al., 2001). Oxidation is likely to occur within the combustion region where $\mathrm{rBC}$ is produced (Frenklach, 2002). In the present study, the presence of $\mathrm{rCO}_{x}$ in the propane-flame samples, CBK and CBW, indicates the potential real-world significance of these SP-AMS species, even in the absence of further aging. Other real-world sources of $\mathrm{rCO}_{x}$, such as metal-oxide fuel additives (Bladt et al., 2012), may also be significant to SP-AMS measurements.

The atmospheric significance of the oxidized surface species which likely lead to $\mathrm{rCO}_{x}$ signals must be considered in context of the overall aerosol. In general, combustion sources emit organic material in addition to $\mathrm{rBC}$. This organic matter is emitted in both the particulate $(\mathrm{OM})$ and the gas phase, and represents a major contribution to the overall composition of the particle. For example, Bond et al. (2013) have recently estimated OM-to-BC ratios between 1 and 10 for primary emissions. After emission, this ratio is likely to increase significantly due to condensation of atmospherically oxidized gas-phase organic compounds. For example, dieselengine OM may increase two-fold after a few hours of moderate atmospheric aging (Robinson et al., 2007), and less efficient processes such as wood combustion may increase OM by seven-fold under similar conditions (e.g., Heringa et al., 2011). These oxidation timescales (hours) are considerably shorter than the atmospheric lifetime of $\mathrm{rBC}$ (days) and produce highly oxidized OM (e.g., Jimenez et al., 2009). Further, coagulation with pre-existing particles also occurs on 
a short timescale (tens of hours) relative to the rBC atmospheric lifetime. Overall, for a global average, neither the bulk nor the surface properties of $\mathrm{rBC}$ are expected to be dominated by $\mathrm{rCO}_{x}$.

On the regional scale, fresh $\mathrm{rBC}$ particles can represent a significant portion of the aerosol near sources, for example within cities (e.g., Seinfeld and Pandis, 2012). These particles may contain a significant fraction of $\mathrm{OM}$, possibly reducing the significance of $\mathrm{rCO}_{x}$ to their overall chemistry. In the absence of $\mathrm{OM}$, freshly-emitted $\mathrm{rBC}$ particles have been measured as cloud-condensation-nucleus inactive (e.g., Kuwata et al., 2009), so $\mathrm{rCO}_{x}$ species are apparently not able to initiate droplet activation on such particles.

Conversely, freshly emitted combustion particles are expected to play a significant role in heterogeneous chemistry, for example, reducing ozone or nitrogen dioxide $\left(\mathrm{NO}_{2}\right)(\mathrm{Mc}-$ Cabe and Abbatt, 2008; Han et al., 2013). Han et al. (2013) found that preheating $n$-hexane soot to $573 \mathrm{~K}$ significantly decreased the uptake of $\mathrm{NO}_{2}$, indicating that volatile $\mathrm{OM}$ was the primary reactant. Furthermore, the yield of gas-phase products simultaneously changed upon heating, indicating that the OM shielded the rBC surface from oxidation. From these results, one may propose that when a freshly produced $\mathrm{rBC}$ particle is coated by $\mathrm{OM}$ the $\mathrm{rBC}$ reactivity may become slow enough that $\mathrm{rCO}_{x}$ could be used as a chemical tracer. For example, the ratio $\mathrm{CO}_{2}^{+} / \mathrm{C}_{3}^{+}$of an OM-denuded $\mathrm{rBC}$ particle may be useful in source apportionment studies. However, this extrapolation must be verified by future laboratory studies using different primary and secondary $\mathrm{OM}$ samples. If this hypothesis is proven false, and $\mathrm{rCO}_{x}$ does in fact increase with atmospheric oxidation, then this SP-AMS signal may be useful in tracking the atmospheric age of rBC.

Finally, $\mathrm{rCO}_{x}$ may be significant for SP-AMS calibration. Neglecting $\mathrm{rCO}_{x}$ during calibration would not only give an inaccurate sensitivity factor, but would lead to the misquantification of $\mathrm{rBC}$ with different degrees of oxidation. Although the elemental analysis of acid-treated $\mathrm{rBC}$ by Figuieredo et al. (1999) suggests an error on the order of $10 \%$, the estimated signal from $\mathrm{CO}^{+}$in Sect. 3.2.1, suggests that the SP-AMS error may be much higher.

\section{Summary}

SP-AMS mass spectra showed just two different overall carbon fragmentation patterns for six $\mathrm{rBC}$ samples generated by a variety of methods, from aircraft-turbine combustion to propane flame combustion to spark vaporization. One group of samples yielded carbon-cluster ions ranging up to a few hundred $m / z$. The other group gave carbon-cluster mass spectra which did not extend appreciably beyond $\mathrm{C}_{5}^{+}$. The two groups could be distinguished according to the ratio $\mathrm{C}_{1}^{+} / \mathrm{C}_{3}^{+}$, which was approximately 1 for the former group and less than 0.8 for the latter.
Two ion ratios were identified for source apportionment, when an air mass contains a mixture of $\mathrm{rBC}$ from the two $\mathrm{C}_{x}^{n+}$ categories. The first ratio, $\mathrm{C}_{1}^{+} / \mathrm{C}_{3}^{+}$, maximizes the $\mathrm{rBC}$ detection limit by using the two most intense $\mathrm{C}_{x}^{n+}$ peaks in the mass spectrum. In this case, thermodenuding of the $\mathrm{rBC}$ sample prior to measurement is recommended due to possible interference by the trace amounts of $\mathrm{C}_{1}^{+}$produced during the fragmentation of $\mathrm{OM}$ ions. The second ratio, $\mathrm{C}_{4}^{+} / \mathrm{C}_{3}^{+}$, aims to avoid this interference by using higher-mass $\mathrm{C}_{x}^{n+}$ ions. The sensitivity of $\mathrm{C}_{4}^{+} / \mathrm{C}_{3}^{+}$to an OM coating was tested using a PAH-rich propane-flame sample (CBW). Further tests with thicker coatings and different chemicals should be performed.

In addition to $\mathrm{C}_{x}^{n+}$ ions, the SP-AMS mass spectrum of all six samples included oxygenated ions. These ions most likely originated from the thermal decomposition of oxygenated moieties within the refractory carbon structure. Their quantification was hindered by high signals from gas-phase molecules such as $\mathrm{N}_{2}^{+}$.

It is not clear whether or not these refractory oxygenated moieties play a role in the heterogeneous chemistry of atmospheric combustion particles. If so, their quantification by SP-AMS could provide a useful measurement of $\mathrm{rBC}$ age. If not, they may be inert enough to allow their SP-AMS signals to be used in source apportionment, since different sources will produce different amounts of oxygenated moieties following differences in the combustion process.

Future work should aim to quantify these ions for a number of samples, also as a function of atmospheric age, to provide a basis for the interpretation of ambient SP-AMS spectra in which gas-phase interferences by $\mathrm{N}_{2}^{+}$are unavoidable. Further studies might also investigate whether the SP-AMS is capable of providing enough information to distinguish between different refractory functional groups, as has been done using well-established offline techniques.

\section{Supplementary material related to this article is available online at http://www.atmos-chem-phys.net/14/ 2591/2014/acp-14-2591-2014-supplement.pdf.}

Acknowledgements. The authors are grateful to M. Johnson (Rolls Royce, UK), T. Rindlisbacher (Federal Office of Civil Aviation, Switzerland), SR Technics (Zurich Airport, Switzerland), P. Williams (University of Manchester, UK), and the SAMPLE-III team for their efforts and assistance during the aircraft-turbine measurements. This work was supported by the Swiss National Fund (Grant 200021_132199/1).

Edited by: H. Saathoff 


\section{References}

Alfarra, M. R.: Insights Into Atmospheric Organic Aerosols Using An Aerosol Mass Spectrometer, Ph.D. Thesis, Department of Chemical Engineering, University of Manchester, 2004.

Bladt, H., Schmid, J., Kireeva, E. D., Popovicheva, O. B., Perseantseva, N. M., Timofeev, M. A., Heister, K., Uihlein, J., Ivleva, N. P., and Niessner, R.: Impact of Fe content in laboratoryproduced soot aerosol on its composition, structure, and thermochemical properties, Aerosol Sci. Tech., 46, 1337-1348, 2012.

Bond, T. C., Doherty, S. J., Fahey, D. W., Forster, P. M., Berntsen, T., DeAngelo, B. J., Flanner, M. G., Ghan, S., Kärcher, B., Koch, D., Kinne, S., Kondo, Y., Quinn, P. K., Sarofim, M. C., Schultz, M. G., Schulz, M., Venkataraman, C., Zhang, H., Zhang, S., Bellouin, N., Guttikunda, S. K., Hopke, P. K., Jacobson, M. Z., Kaiser, J. W., Klimont, Z., Lohmann, U., Schwarz, J. P., Shindell, D., Storelvmo, T., Warren, S. G., and Zender, C. S.: Bounding the role of black carbon in the climate system: A scientific assessment, J. Geophys. Res., 118, 5380-5552, doi:10.1002/jgrd.50171, 2013.

Burtscher, H.: Physical characterization of particulate emissions from diesel engines: a review, J. Aerosol Sci., 36, 896-932, 2005.

Canagaratna, M., Jayne, J., Jimenez, J., Allan, J., Alfarra, M., Zhang, Q., Onasch, T. B., Drewnick, F., Coe, H., Middlebrook, A., Delia, A., Williams, L., Trimborn, A., Northway, M., DeCarlo, P., Kolb, C., Davidovits, P., and Worsnop, D.: Chemical and microphysical characterization of ambient aerosols with the aerodyne aerosol mass spectrometer, Mass Spectrom. Rev., 26, 185-222, doi:10.1002/mas.20115, 2007.

Cape, J. N., Coyle, M., and Dumitrean, P.: The atmospheric lifetime of black carbon, Atmos. Environ., 59, 256-263, doi:10.1016/j.atmosenv.2012.05.030, 2012.

Cappa, C. D., Onasch, T. B., Massoli, P., Worsnop, D. R., Bates, T. S., Cross, E. S., Davidovits, P., Hakala, J., Hayden, K. L., and Jobson, B. T.: Radiative absorption enhancements due to the mixing state of atmospheric black carbon, Science, 337, 1078-1081, 2012.

Cappa, C. D., Onasch, T. B., Massoli, P., Worsnop, D. R., Bates, T. S., Cross, E. S., Davidovits, P., Hakala, J., Hayden, K. L., and Jobson, B. T.: Response to Comment on "Radiative absorption enhancements due to the mixing state of atmospheric black carbon", Science, 339, 393-393, 2013.

Corbin, J., Rehbein, P., Evans, G., and Abbatt, J.: Combustion particles as ice nuclei in an urban environment: evidence from singleparticle mass spectrometry, Atmos. Environ., 51, 286-292, 2012.

Crayford, A., Johnson, M., Marsh, R., Secvenco, Y., Walters, D., Williams, P., Petzold, A., Bowen, P., Wang, J., and Lister, D.: SAMPLE III: Contribution to aircraft engine PM certification requirement and standard, Second Specific Contract, Final Report, European Aviatian Safety Agency, Cologne, Germany, 2012.

DeMott, P. J., Chen, Y., Kreidenweis, S. M., Rogers, D. C., and Sherman, D. E.: Ice formation by black carbon particles, Geophys. Res. Lett., 26, 2429-2432, doi:10.1029/1999gl900580, 1999.

Díaz-Tendero, S., Martín, F., and Alcamí, M.: Structure, Dissociation Energies, and Harmonic Frequencies of Small Doubly Charged Carbon Clusters $\mathrm{C}^{n} 2+(n=3-9)$, J. Phys. Chem. A, 106, 10782-10789, 2002.

Engelhart, G. J., Hennigan, C. J., Miracolo, M. A., Robinson, A. L., and Pandis, S. N.: Cloud condensation nuclei activity of fresh primary and aged biomass burning aerosol, Atmos. Chem. Phys., 12, 7285-7293, doi:10.5194/acp-12-7285-2012, 2012.

Figueiredo, J., Pereira, M., Freitas, M., and Orfao, J.: Modification of the surface chemistry of activated carbons, Carbon, 37, 13791389, 1999.

Figueiredo, J. L., Pereira, M. F., Freitas, M. M., and Órfão, J. J.: Characterization of active sites on carbon catalysts, Ind. Eng. Chem. Res., 46, 4110-4115, 2007.

Flanner, M. G., Zender, C. S., Randerson, J. T., and Rasch, P. J.: Present-day climate forcing and response from black carbon in snow, J. Geophys. Res., 112, D11202, doi:10.1029/2006JD008003, 2007.

Frenklach, M.: Reaction mechanism of soot formation in flames, Phys. Chem. Chem. Phys., 4, 2028-2037, 2002.

Gysel, M., Laborde, M., Mensah, A. A., Corbin, J. C., Keller, A., Kim, J., Petzold, A., and Sierau, B.: Technical Note: The single particle soot photometer fails to reliably detect PALAS soot nanoparticles, Atmos. Meas. Tech., 5, 3099-3107, doi:10.5194/amt-5-3099-2012, 2012.

Han, C., Liu, Y., and He, H.: Role of Organic Carbon in Heterogeneous Reaction of $\mathrm{NO}_{2}$ with Soot, Environ. Sci. Technol., 47, 3174-3181, 2013.

Healy, R. M., Sciare, J., Poulain, L., Crippa, M., Wiedensohler, A., Prévôt, A. S. H., Baltensperger, U., Sarda-Estève, R., McGuire, M. L., Jeong, C.-H., McGillicuddy, E., O'Connor, I. P., Sodeau, J. R., Evans, G. J., and Wenger, J. C.: Quantitative determination of carbonaceous particle mixing state in Paris using single-particle mass spectrometer and aerosol mass spectrometer measurements, Atmos. Chem. Phys., 13, 9479-9496, doi:10.5194/acp13-9479-2013, 2013.

Helsper, C., Mölter, W., Löffler, F., Wadenpohl, C., Kaufmann, S., and Wenninger, G.: Investigations of a new aerosol generator for the production of carbon aggregate particles, Atmos. Environ. 27, 1271-1275, doi:10.1016/0960-1686(93)90254-V, 1993.

Heringa, M. F., DeCarlo, P. F., Chirico, R., Tritscher, T., Dommen, J., Weingartner, E., Richter, R., Wehrle, G., Prévôt, A. S. H., and Baltensperger, U.: Investigations of primary and secondary particulate matter of different wood combustion appliances with a high-resolution time-of-flight aerosol mass spectrometer, Atmos. Chem. Phys., 11, 5945-5957, doi:10.5194/acp-11-59452011, 2011.

Hitzenberger, R., Giebl, H., Petzold, A., Gysel, M., Nyeki, S., Weingartner, E., Baltensperger, U., and Wilson, C.: Properties of jet engine combustion particles during the PartEmis experiment. Hygroscopic growth at supersaturated conditions, Geophys. Res. Lett., 30, 1779, doi:10.1029/2003GL017294, 2003.

IPCC: Contribution of Working Group I to the Fourth Assessment Report of the Intergovernmental Panel on Climate Change, edited by: Solomon, S., Qin, D., Manning, M., Chen, Z., Marquis, M., Averyt, K. B., Tignor, M., and Miller, H. L., Cambridge University Press, UK and New York, NY, USA, 2007.

Jacobson, M. Z.: Comment on "Radiative absorption enhancements due to the mixing state of atmospheric black carbon", Science, 339, 393-393, 2013.

Jayne, J. T., Leard, D. C., Zhang, X., Davidovits, P., Smith, K. A., Kolb, C. E., and Worsnop, D. R.: Development of an aerosol mass spectrometer for size and composition analysis of submicron particles, Aerosol Sci. Tech., 33, 49-70, doi:10.1080/027868200410840, 2000. 
Jeong, C.-H., Herod, D., Dabek-Zlotorzynska, E., Ding, L., McGuire, M., and Evans, G.: Identification of the Sources and Geographic Origins of Black Carbon using Factor Analysis at Paired Rural and Urban sites, Environ. Sci. Technol., 47, 84628470, doi:10.1021/es304695t, 2013.

Jimenez, J. L., Jayne, J. T., Shi, Q., Kolb, C. E., Worsnop, D. R., Yourshaw, I., Seinfeld, J. H., Flagan, R. C., Zhang, X., Smith, K. A., Morris, J. W., and Davidovits, P.: Ambient aerosol sampling using the Aerodyne Aerosol Mass Spectrometer, J. Geophys. Res., 108, 8425, doi:10.1029/2001jd001213, 2003.

Jimenez, J. L., Canagaratna, M. R., Donahue, N. M., Prévôt, A. S. H., Zhang, Q., Kroll, J. H., DeCarlo, P. F., Allan, J. D., Coe, H., Ng, N. L., Aiken, A. C., Docherty, K. S., Ulbrich, I. M., Grieshop, A. P., Robinson, A. L., Duplissy, J., Smith, J. D., Wilson, K. R., Lanz, V. A., Hueglin, C., Sun, Y. L., Tian, J., Laaksonen, A., Raatikainen, T., Rautiainen, J., Vaattovaara, P., Ehn, M., Kulmala, M., Tomlinson, J. M., Collins, D. R., Cubison, M. J., Dunlea, E. J., J., Huffman, J. A., Onasch, T. B., Alfarra, M. R., Williams, P. I., Bower, K., Kondo, Y., Schneider, J., Drewnick, F., Borrmann, S., Weimer, S., Demerjian, K., Salcedo, D., Cottrell, L., Griffin, R., Takami, A., Miyoshi, T., Hatakeyama, S., Shimono, A., Sun, J. Y., Zhang, Y. M., Dzepina, K., Kimmel, J. R., Sueper, D., Jayne, J. T., Herndon, S. C., Trimborn, A. M., Williams, L. R., Wood, E. C., Middlebrook, A. M., Kolb, C. E., Baltensperger, U., and Worsnop, D. R.: Evolution of Organic Aerosols in the Atmosphere, Science, 326, 1525-1529, 2009.

Koehler, K. A., DeMott, P. J., Kreidenweis, S. M., Popovicheva, O. B., Petters, M. D., Carrico, C. M., Kireeva, E. D., Khokhlova, T. D., and Shonija, N. K.: Cloud condensation nuclei and ice nucleation activity of hydrophobic and hydrophilic soot particles, Phys. Chem. Chem. Phys., 11, 7906-7920, 2009.

Krätschmer, W., Fostiropoulos, K., and Huffman, D. R.: The infrared and ultraviolet absorption spectra of laboratory-produced carbon dust: evidence for the presence of the $\mathrm{C}_{60}$ molecule, Chem. Phys. Lett., 170, 167-170, 1990.

Kuwata, M., Kondo, Y., and Takegawa, N.: Critical condensed mass for activation of black carbon as cloud condensation nuclei in Tokyo, J. Geophys. Res., 114, D20202, doi:10.1029/2009JD012086, 2009.

Laborde, M., Mertes, P., Zieger, P., Dommen, J., Baltensperger, U., and Gysel, M.: Sensitivity of the Single Particle Soot Photometer to different black carbon types, Atmos. Meas. Tech., 5, 10311043, doi:10.5194/amt-5-1031-2012, 2012.

Liu, D., Allan, J., Whitehead, J., Young, D., Flynn, M., Coe, H., McFiggans, G., Fleming, Z. L., and Bandy, B.: Ambient black carbon particle hygroscopic properties controlled by mixing state and composition, Atmos. Chem. Phys., 13, 2015-2029, doi:10.5194/acp-13-2015-2013, 2013.

Martin, M., Tritscher, T., Jurányi, Z., Heringa, M. F., Sierau, B., Weingartner, E., Chirico, R., Gysel, M., Prévôt, A. S., and Baltensperger, U.: Hygroscopic properties of fresh and aged wood burning particles, J. Aerosol Sci., 56, 15-29, 2012.

Matt, S., Dünser, B., Lezius, M., Deutsch, H., Becker, K., Stamatovic, A., Scheier, P., and Märk, T.: Absolute partial and total cross-section functions for the electron impact ionization of $\mathrm{C}_{60}$ and $\mathrm{C}_{70}$, J. Chem. Phys., 105, 1880-1896, 1996.
McCabe, J. and Abbatt, J.: Heterogeneous loss of gas-phase ozone on n-hexane soot surfaces: similar kinetics to loss on other chemically unsaturated solid surfaces, J. Phys. Chem. C, 113, 21202127, 2008.

Monge, M. E., D’Anna, B., Mazri, L., Giroir-Fendler, A., Ammann, M., Donaldson, D., and George, C.: Light changes the atmospheric reactivity of soot, P. Natl. Acad. Sci. USA, 107, 66056609, 2010.

Moteki, N. and Kondo, Y.: Dependence of laser-induced incandescence on physical properties of black carbon aerosols: measurements and theoretical interpretation, Aerosol Sci. Tech., 44, 663675, doi:10.1080/02786826.2010.484450, 2010.

Onasch, T. B., Trimborn, A., Fortner, E. C., Jayne, J. T., Kok, G. L., Williams, L. R., Davidovits, P., and Worsnop, D. R.: Soot particle aerosol mass spectrometer: development, validation, and initial application, Aerosol Sci. Tech., 46, 804-817, doi:10.1080/02786826.2012.663948, 2012.

Otake, Y. and Jenkins, R. G.: Characterization of oxygen-containing surface complexes created on a microporous carbon by air and nitric acid treatment, Carbon, 31, 109-121, 1993.

Park, K., Kittelson, D. B., Zachariah, M. R., and McMurry, P. H.: Measurement of inherent material density of nanoparticle agglomerates, J. Nanopart. Res., 6, 267-272, 2004.

Petzold, A. and Schönlinner, M.: Multi-angle absorption photometry - a new method for the measurement of aerosol light absorption and atmospheric black carbon, J. Aerosol Sci., 35, 421-441, 2004.

Pratt, K. A. and Prather, K. A.: Mass spectrometry of atmospheric aerosols - recent developments and applications, Part II: On-line mass spectrometry techniques, Mass Spectrom. Rev., 31, 17-48, 2012.

Raghavachari, K. and Binkley, J.: Structure, stability, and fragmentation of small carbon clusters, J. Chem. Phys., 87, 2191-2197, 1987.

Ramanathan, V. and Carmichael, G.: Global and regional climate changes due to black carbon, Nat. Geosci., 1, 221-227, 2008.

Reilly, P. T. A., Lazar, A. C., Gieray, R. A., Whitten, W. B., and Ramsey, J. M.: The elucidation of Charge-Transfer-Induced Matrix effects in environmental aerosols via real-time aerosol mass spectral analysis of individual airborne particles, Aerosol Sci. Tech., 33, 135-152, 2000.

Reinard, M. S. and Johnston, M. V.: Ion formation mechanism in laser desorption ionization of individual nanoparticles, J. Am. Soc. Mass Spectr., 19, 389-399, 2008.

Robertson, J.: Diamond-like amorphous carbon, Mat. Sci. Eng., 37, 129-281, 2002.

Robinson, A. L., Donahue, N. M., Shrivastava, M. K., Weitkamp, E. A., Sage, A. M., Grieshop, A. P., Lane, T. E., Pierce, J. R., and Pandis, S. N.: Rethinking organic aerosols: Semivolatile emissions and photochemical aging, Science, 315, 1259-1262, 2007.

Saathoff, H., Naumann, K. H., Riemer, N., Kamm, S., Möhler, O., Schurath, U., Vogel, H., and Vogel, B.: The loss of $\mathrm{NO}_{2}, \mathrm{HNO}_{3}$, $\mathrm{NO}_{3} / \mathrm{N}_{2} \mathrm{O}_{5}$, and $\mathrm{HO}_{2} / \mathrm{HOONO}_{2}$ on soot aerosol: a chamber and modeling study, Geophys. Res. Lett., 28, 1957-1960, 2001.

Saathoff, H., Moehler, O., Schurath, U., Kamm, S., Dippel, B., and Mihelcic, D.: The AIDA soot aerosol characterisation campaign 1999, J. Aerosol Sci., 34, 1277-1296, doi:10.1016/S00218502(03)00363-X, 2003. 
Sandradewi, J., Prévôt, A. S., Szidat, S., Perron, N., Alfarra, M. R., Lanz, V. A., Weingartner, E., and Baltensperger, U.: Using aerosol light absorption measurements for the quantitative determination of wood burning and traffic emission contributions to particulate matter, Environ. Sci. Technol., 42, 3316-3323, 2008.

Scheier, P., Dünser, B., Wörgötter, R., Lezius, M., Robl, R., and Märk, T.: Appearance and ionization energies of singly, doubly and triply charged $\mathrm{C}_{60}$ and its fragment ions produced by electron impact ionization, Int. J. Mass Spectrom, 138, 77-93, 1994.

Schmid, J., Grob, B., Niessner, R., and Ivleva, N.: Multiwavelength Raman microspectroscopy for rapid prediction of soot oxidation reactivity, Anal. Chem., 83, 1173-1179, doi:10.1021/ac102939w, 2011.

Schneider, J., Weimer, S., Drewnick, F., Borrmann, S., Helas, G., Gwaze, P., Schmid, O., Andreae, M., and Kirchner, U.: Mass spectrometric analysis and aerodynamic properties of various types of combustion-related aerosol particles, Int. J. Mass Spectrom., 258, 37-49, 2006.

Schwarz, J. P., Gao, R. S., Fahey, D. W., Thomson, D. S., Watts, L. A., Wilson, J. C., Reeves, J. M., Darbeheshti, M., Baumgardner, D. G., Kok, G. L., Chung, S. H., Schulz, M., Hendricks, J., Lauer, A., Kärcher, B., Slowik, J. G., Rosenlof, K. H., Thompson, T. L., Langford, A. O., Loewenstein, M., and Aikin, K. C.: Single-particle measurements of midlatitude black carbon and light-scattering aerosols from the boundary layer to the lower stratosphere, J. Geophys. Res., 111, D16207, doi:10.1029/2006JD007076, 2006.

Seinfeld, J. H. and Pandis, S. N.: Atmospheric chemistry and physics: from air pollution to climate change, John Wiley \& Sons, New Jersey, USA, 2012.

Sellitti, C., Koenig, J., and Ishida, H.: Surface characterization of graphitized carbon fibers by attenuated total reflection Fourier transform infrared spectroscopy, Carbon, 28, 221-228, 1990.

Sevilla, M. and Fuertes, A. B.: Sustainable porous carbons with a superior performance for $\mathrm{CO}_{2}$ capture, Energy Environ. Sci., 4, 1765-1771, 2011.

Shindell, D., Kuylenstierna, J., Vignati, E., van Dingenen, R., Amann, M., Klimont, Z., Anenberg, S., Muller, N., JanssensMaenhout, G., Raes, F., Schwartz, J., Faluvegi, G., Pozzoli, L., Kupiainen, K., Höglund-Isaksson, L., Emberson, L., Streets, D., Ramanathan, V., Hicks, K., Oanh, N., Milly, G., Williams, M., Demkine, V., and Fowler, D.: Simultaneously mitigating nearterm climate change and improving human health and food security, Science, 335, 183-189, doi:10.1126/science.1210026, 2012.

Slowik, J. G., Cross, E. S., Han, J.-H., Davidovits, P., Onasch, T. B., Jayne, J. T., Williams, L. R., Canagaratna, M. R., Worsnop, D. R., Chakrabarty, T. K., Moosmüller, J., Arnott, E. P., Schwarz, J. P., Gao, R.-S., Fahey, F. W., Kok, G. L., and Petzold, A.: An inter-comparison of instruments measuring black carbon content of soot particles, Aerosol Sci. Tech., 41, 295-314, doi:10.1080/02786820701197078, 2007.
Toner, S. M., Shields, L. G., Sodeman, D. A., and Prather, K. A.: Using mass spectral source signatures to apportion exhaust particles from gasoline and diesel powered vehicles in a freeway study using UF-ATOFMS, Atmos. Environ., 42, 568-581, 2008.

Tritscher, T., Jurányi, Z., Martin, M., Chirico, R., Gysel, M., Heringa, M. F., DeCarlo, P. F., Sierau, B., Prévôt, A. S., and Weingartner, E.: Changes of hygroscopicity and morphology during ageing of diesel soot, Environ. Res. Lett., 6, 034026, doi:10.1088/1748-9326/6/3/034026, 2011.

Vinke, P., Van der Eijk, M., Verbree, M., Voskamp, A., and Van Bekkum, H.: Modification of the surfaces of a gasactivated carbon and a chemically activated carbon with nitric acid, hypochlorite, and ammonia, Carbon, 32, 675-686, 1994.

von Helden, G., Hsu, M. T., Gotts, N., and Bowers, M. T.: Carbon cluster cations with up to 84 atoms: structures, formation mechanism, and reactivity, J. Phys. Chem., 97, 8182-8192, 1993.

Weingartner, E., Baltensperger, U., and Burtscher, H.: Growth and structural change of combustion aerosols at high relative humidity, Environ. Sci. Technol., 29, 2982-2986, 1995.

Wiedensohler, A., Birmili, W., Nowak, A., Sonntag, A., Weinhold, K., Merkel, M., Wehner, B., Tuch, T., Pfeifer, S., Fiebig, M., Fjäraa, A. M., Asmi, E., Sellegri, K., Depuy, R., Venzac, H., Villani, P., Laj, P., Aalto, P., Ogren, J. A., Swietlicki, E., Williams, P., Roldin, P., Quincey, P., Hüglin, C., Fierz-Schmidhauser, R., Gysel, M., Weingartner, E., Riccobono, F., Santos, S., Grüning, C., Faloon, K., Beddows, D., Harrison, R., Monahan, C., Jennings, S. G., O’Dowd, C. D., Marinoni, A., Horn, H.-G., Keck, L., Jiang, J., Scheckman, J., McMurry, P. H., Deng, Z., Zhao, C. S., Moerman, M., Henzing, B., de Leeuw, G., Löschau, G., and Bastian, S.: Mobility particle size spectrometers: harmonization of technical standards and data structure to facilitate high quality long-term observations of atmospheric particle number size distributions, Atmos. Meas. Tech., 5, 657-685, doi:10.5194/amt5-657-2012, 2012.

Winklmayr, W., Reischl, G. P., Lindner, A. O., and Berner, A.: A new electromobility spectrometer for the measurement of aerosol size distributions in the size range from 1 to $1000 \mathrm{~nm}$, J. Aerosol Sci., 22, 289-296, 1991.

Zencak, Z., Elmquist, M., and Gustafsson, Ö.: Quantification and radiocarbon source apportionment of black carbon in atmospheric aerosols using the CTO-375 method, Atmos. Environ., 41, 7895-7906, 2007.

Zhang, Q., Jimenez, J. L., Canagaratna, M. R., Ulbrich, I. M., $\mathrm{Ng}$, N. L., Worsnop, D. R., and Sun, Y.: Understanding atmospheric organic aerosols via factor analysis of aerosol mass spectrometry: a review, Anal. Bioanal. Chem., 401, 3045-3067, 2011

Zielke, U., Hüttinger, K., and Hoffman, W.: Surface-oxidized carbon fibers: I. Surface structure and chemistry, Carbon, 34, 983998, 1996.

Zimmerman, J. A., Eyler, J. R., Bach, S. B., and McElvany, S. W.: "Magic number" carbon clusters: ionization potentials and selective reactivity, J. Chem. Phys., 94, 3556-3562, 1991. 